\title{
PENYEBAB BERALIHNYA TEKNOLOGI DARI PEMILIK KEPADA PENERIMA
}

\author{
Bakti Trisnawati *
}

\begin{abstract}
Technology Transfer needs to be done, as long as it benefits the nation's economy. Technology transfer contracts are not only limited to the regulation of rights and obligations, but further implementation is still needed. Because the technology transfer contract has a relationship with the environment and society. As a result, it can affect the economic life of the country. In such conditions the need for government intervention in making technology transfer contracts. There is government interference, meaning there must be legal intervention. All of this should be explicitly reflected in the technology transfer contract agreement. Making agreements or contracts that are solely left to the operation of the principle of the principle of freedom of contract, will always be an arena of struggle for dominance between the parties to the agreement. Usually as a party that receives technology (in this case developing countries) is in a weak position, while the technology provider / owner is in a strong position. Thus the strong party will dominate the weak party, so that this situation often brings the result of a one-sided contract.
\end{abstract}

Keywords: Technology Transfer, Owner to Recipients, Causes.

\section{PENDAHULUAN}

Alih Teknologi perlu dilakukan, sepanjang menguntungkan perekonomian bangsa. Mekanisme alih teknologi juga mencakup transaksi-transaksi dagang internasional mengenai teknologi yang berbeda di tiap negara yang bergantung kepada keadaan politik dan ekonomi serta taraf kemajuan teknologi dari negara yang bersangkutan. Memang betul tujuan kontrak adalah untuk mengatur hak dan kewajiban (hubungan para pihak). ${ }^{1}$

Dalam hal kontrak alih teknologi tidak hanya sebatas pada pengaturan hak dan kewajiban. Masih diperlukan pelaksanaan lebih lanjut setelah selesainya penyerahan hak dan kewajiban, sebab

* Bakti Trisnawati adalah Pengajar di Universitas 17 Agustus 1945 Semarang dapat dihubungi melalui email : baktitrisnawati@gmail.com

1 Sudikno Mertokusumo, 1998, Mengenal Hukum (Suatu pengantar), Liberty, Yogyakarta, hal.53. dalam kontrak alih teknologi mempunyai keterkaitan dengan banyak bidang, termasuk di dalamnya lingkungan dan masyarakat. Akibatnya, dapat berpengaruh pada kehidupan ekonomi negara. Dalam kondisi demikian perlu campur tangan pemerintah dalam pembuatan kontrak alih teknologi.

Namun perlu diingat dalam hal ada campur tangan pemerintah, sehingga akhirnya harus ada campur tangan hukum, haruslah diterapkan dalam batas-batas tertentu yang wajar. Hal ini memang diperlukan dan jangan sampai berlebihan. ${ }^{2}$ Dengan demikian kontrak alih teknologi di samping mengatur hubungan para pihak tentang hak dan kewajiban, juga diperlukan terciptanya suatu posisi tawar yang seimbang.

2 Rudhi Prasetya, 1993, Perseroan Terbatas Sebagai Wahana Membahagiakan dan Menestapakan, Makalah, 1 Mei 1993, Surabaya, hal.8. 
Semua ini hendaknya tercermin secara tegas dalam perjanjian kontrak alih teknologi. Campur tangan pemerintah perlu mempertimbangkan tingkat pengalihan teknologi yang tepat dan berdayaguna di bidang industri. Tampaknya campur tangan pemerintah dalam memilih secara tepat alih teknologi yang mana yang dapat mengembangkan bidang industri merupa kan prioritas.

Sehubungan dengan itu, seyogya nya akan lebih efektif jika pemerintah melakukan intervensi dalam bentuk pemberian izin untuk masuknya teknologi sebagai alternatif untuk menyaring perjanjian lisensi yang ada hubungannya dengan alih teknologi.

Dalam pembuatan setiap perjanjian selalu berlangsung dengan berlandaskan pada asas konsensualisme dan kebebasan berkontrak sebagai asas hukum perjanjian. ${ }^{3}$

Pembuatan perjanjian atau kontrak yang semata-mata hanya diserahkan kepada bekerjanya mekanisme asas kebebasan berkontrak, akan selalu menjadi ajang perebutan dominasi di antara para pihak dalam perjanjian tersebut. Biasanya sebagai pihak yang menerima teknologi (dalam hal ini negara berkembang) berada dalam posisi yang lemah, sedangkan pemberi/pemilik teknologi berada dalam posisi yang kuat. Dengan demikian pihak yang kuat akan mendominasi pihak yang lemah, sehingga keadaan ini sering membawa akibat terjadinya kontrak yang berat sebelah.

Berdasarkan apa yang telah diuraikan di atas, maka penulis tertarik untuk menulis makalah dengan judul : “ Penyebab Beralihnya Teknologi Dari Pemilik Kepada Penerima".

\section{Perumusan Masalah}

Dalam makalah ini perumusan masalahnya adalah : Apa yang menjadi

3 Op Cit, hal.99. penyebab beralihnya teknologi dari pemilik kepada penerima?

\section{Pembahasan}

Teknologi menurut United Nations Conference on Transnational Corporations (UNTC) dapat diartikan secara sempit dan secara luas. Dalam arti sempit, teknologi adalah keahlian manusia yang diperlukan untuk penerapan teknik-teknik itu yang dapat dianggap sebagai teknologi. Sedangkan secara luas teknologi meliputi barang-barang modal yaitu alat-alat, mesinmesin dan seluruh sistem produksi yang boleh dikatakan sebagai teknologi

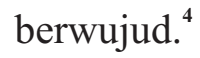

Teknologi merupakan syarat mutlak dalam pembangunan ekonomi karena dengan teknologi dapat diperoleh efisiensi dan produktifitas yang lebih besar dalam kaitannya dengan sumber-sumber yang dipergunakan. Ini berarti bahwa dilihat dari segi ekonomi, alih teknologi memungkin kan pelipatgandaan keuntungan. ${ }^{5}$

Pembangunan ekonomi merupakan suatu tindakan untuk mendayagunakan input yang lebih banyak guna menghasil kan output yang lebih banyak pula. Aktivitas ini memerlukan teknologi karena teknologi dapat menghasilkan input lebih banyak. Bahkan, melakukan inovasi terhadap input tersebut yang selanjutnya dapat melipatgandakan output. ${ }^{6}$

Berdasarkan pemikiran itu, dapat dikatakan bahwa alih teknologi merupakan sesuatu yang mutlak diperlukan di dalam pembangunan ekonomi negara-negara sedang berkembang.

Sedangkan UNCTC mengartikan alih teknologi sebagai proses memperoleh

4 Dewi Astuty, 2001, Perjanjian Lisensi Alih Teknologi Dalam Pengembangan Teknologi Indonesia, PT.Alumni, Bandung, hal.46.

5 Peter Mahmud Marzuki, 1993, Pengaturan Hukum Terhadap Perusahaan-perusahaan Transnasional di Indonesia, Disertasi, Universitas Airlangga, Surabaya, hal 98. 6 Ibid, hal 99. 
kemampuan teknologi dari luar negeri. ${ }^{7}$ Baik yang dikemukakan oleh UNCTAD maupun UNCTC sebenarnya merupakan penjelasan lebih lanjut dari pengertian yang telah dikemukakan di atas.

Selanjutnya ada seorang sarjana yang membedakan antara mobilisasi teknologi dan alih teknologi. Mobilisasi teknologi adalah memindahkan teknologi dari satu tempat ke tempat lain tanpa perlu mengalihkan pengetahuan yang ada di belakang teknologi itu. Misalnya mobilisasi teknologi sebagai penjualan mesin-mesin. Melalui penjualan mesin-mesin, pihak produser atau pemasok mesin hanya menunjukkan kepada pembeli bagaimana caranya menggunakan atau mengoperasi kan mesin-mesin itu.

Disini pembeli mesin tidak mempunyai kemampuan untuk mengetahui rahasia teknis mesin-mesin itu. Bahkan seringkali untuk mereparasi mesin-mesin itu pihak pemasok juga mengirim teknisinya kepada pembeli. Dalam keadaan seperti itu tidak terjadi alih teknologi.

Sebaliknya yang terjadi hanya pemindahan produk teknologi secara pisik dari suatu tempat ke tempat lain tanpa memindahkan pengetahuan pembuatan mesin-mesin itu.

Sedangkan untuk proses alih teknologi itu dapat terjadi melalui cara lisensi atau penanaman modal secara langsung. Sebab alih teknologi memang merupakan suatu proses yang dapat mempengaruhi hampir setiap aspek perubahan ekonomi dan sosial suatu masyarakat. Akibat dari proses alih teknologi menimbulkan permasalahanpermasalahan, sehingga perlu adanya langkah-langkah pengaturan yaitu : langkah pengaturan yang memberikan pengaruh umum dan langkah-langkah yang khusus dengan proses alih teknologi.

Indonesia sebagai suatu negara berkembang menyadari juga bahwa ilmu pengetahuan dan alih teknologi mempunyai

7 Ibid hal.58 peranan penting dalam mempercepat pembangunan sosial-ekonomi nasional, khususnya untuk mempercepat peningkat an produksi barang dan jasa dalam sektor industri. Disinilah perlu memasukkan teknologi asing yang tepat dari luar negara ke dalam negara dengan ketentuanketentuan dan syarat-syarat harga yang memungkinkan bagi kepentingan nasional.

Guna memberikan nilai yang langgeng untuk negara Indonesia, teknologi asing yang dimasukkn harus diseleksi sedemikian rupa sehingga efektif dapat diasimilasikan dan disesuaikan dengan kebutuhan Indonesia. Oleh karena itu, harus didapatkan penguraian lengkap mengenai teknologi (full disclosure) dari informasi teknologi yang diperlukan ${ }^{8}$ namun, perlu dikemukakan disini bahwa pemilik teknologi dapat dimaklumi kalau enggan untuk mengungkapkan secara keseluruhan rahasia teknologinya. Hal itu disebabkan dilihat dari segi bisnis, perusahaan menciptakan teknologi bukan untuk dijual atau dialihkan. Teknologi diciptakan untuk dipergunakan dalam kesempatan bisnis. Oleh karena itu, lisensi terhadap alih teknologi hanya dimungkin kan apabila analisis menunjukkan bahwa penggunaan teknologi oleh perusahaan itu sendiri tidak "feasible".

Selain itu alih teknologi juga merupakan upaya dari negara-negara sedang berkembang untuk mengendurkan kebergantungan kepada negara maju. Menurut catatan Marzuki, pada awal pembangunan ekonominya, dalam rangka mengurangi kebergantungan ekonomis negara-negara sedang berkembang kepada negara-negara maju, negara-negara sedang berkembang mendirikan industri-industri dengan membeli teknologi dengan membeli teknologi-teknologi dari negaranegara maju. Hal itu berlangsung pada

8 Ita Gambiro, Pemindahan Teknologi dan Pengaturannya Dalam Peraturan Perundang an, Makalah, dalam : Seminar Aspek-aspek Hukum Dari Pengalihan teknologi, Tanggal 2-4 November 1978, Binacipta, Manado, hal 168. 
tahun 1960-an.' Tidak dapat dipungkiri bahwa dengan melancarkan kebijaksanaan tersebut secara ekonomi, negara-negara sedang berkembang memang mampu sedikit mengurangi kebergantungannya kepada perusahaan transnasional. Karena bekerjanya industri-industtri di Negaranegara sedang berkembang dimungkinkan, berkat pembelian teknologi dari luar negeri. $^{10}$

Alih Teknologi tersebut dapat dilakukan melalui perjanjian lisensi paten, yang mana hal tersebut diatur dalam Undang-Undang Paten No. 14 Tahun 2001 Pasal 69 - 73. Namun rincian ketentuan mengenai lisensi dalam wujud peraturan pelaksanaannya sampai kini belum ditetapkan. Ini berarti bahwa perjanjian alih teknologi diatur berdasarkan ketentuan KUH Perdata, sedangkan pemberian lisensi paten berdasarkan ketentuan UndangUndang Paten.

Perjanjian pemberian lisensi paten ini juga merupakan salah satu jenis lisensi industrial yang umumnya diatur dalam Hukum Perdata, Selanjutnya, dikatakannya bahwa perjanjian lisensi paten tidak berbeda dengan perjanjian perorangan lainnya. Hak-hak untuk menikmati dan menegakkan ketentuan-ketentuan lisensi bergantung kepada sifat kontraktual lisensi itu, daripada kenyataan terlibatnya hak-hak paten. ${ }^{11}$ Berbeda dengan pendapat tersebut di atas ialah yang dikemukakan oleh Sumantoro, yaitu bahwa perjanjian lisensi adalah kontrak pemberian teknologi untuk menggunakan hak proses dengan imbalan ${ }^{12}$

Perjanjian lisensi paten berbeda dari perjanjian umum lainnya, karena pemilik paten atau pemegang paten hanya memberikan lisensi kepada penerima lisensi, sedangkan hak patennya masih tetap menjadi milik pemilik paten tersebut

9 Op Cit, hal. 99.

10 Dewi Astutty, Op Cit hal.58.

11 Insan Budi Maulana, 1996, Lisensi Paten, PT Citra Aditya Bakti, Bandung, , hal. 21.

12 Sumantoro,1993, Masalah Pengaturan Alih Teknologi, Alumni, Bandung, hal. 110. dan bukan menjadi milik penerima lisensi. Sebagi aturan umum, lisensi paten bersifat personal dan tidak dapat dialihkan, kecuali jika syarat-syarat yang terdapat dalam perjanjian tersebut menunjukkan adanya maksud untuk mengizinkan pengalihan.

Konsep alih teknologi dengan melisensikan hasil-hasil penemuan pun semakin meluas dan diadopsi, baik oleh lembaga penelitian independen maupun universitas. Dana dari hasil lisensi teknologi oleh lembaga penelitian dan universitas selanjutnya dapat digunakan untuk membiayai penelitian lebih lanjut dan menjadi insentif bagi para peneliti serta pihak yang melisensi, yaitu industry, memperoleh keuntungan dengan dapat mengakses teknologi dasar masa depan yang dikembangkan oleh lembaga-lembaga tersebut.

Berbicara tentang masalah alih teknologi sesungguhnya merupakan kepentingan negara penerima dan pengalih secara timbal balik. Pihak penerima mengharapkan dapat menerapkan, mengembangkan, dan menguasai teknologi yang dialihkan. Sementara bagi Negara pengalih, teknologi yang paling canggih sekalipun tidak dapat lagi dijadikan mili sendiri negara maju tersebut. Kepentingan lain Negara pengalih berkaitan perluasan pasar hasil teknologi yang dikuasainya. Dalam kaitan ini perlu disadari bahwa laju pertumbuhan teknologi selain dipengaruhi oleh besarnya dana yang disediakan untuk kegiatan penelitian dan pengembangan (research and development), juga dipengaruhi oleh jumlah sarjana yang bekerja di lingkungan penelitian dan pengembangan dan industry. Sedangkan hal-hal yang sangat berpengaruh terhadap tingkat keberhasilan dalam proses alih teknologi adalah:

1. Kerja sama yang serasi antara pengalih dan penerima teknologi yang dilandasi oleh semangat saling menguntungkan.

2. Persiapan-persiapan secara matang guna mengatasi kendala-kendala yang 
terjadi di pihak pengalih dan penerima.

3. Kedua belah pihak harus bersikap bersahabat.

Secara umum, perangsang paling besar bagi pemilik teknologi untuk mengalihkan ke Negara penerima adalah:

1. Terbukanya peluang untuk perluasan pasar, peningkatan volume penjualan, dan peningkatan dana bagi penelitian dan pengembangan untuk memajukan teknologi lebih lanjut, antara lain dengan program kerja sama penelitian dan pengembangan antara pihak pengalih dan penerima.

2. Balas jasa langsung dan tidak langsung yang disebut uang jasa lisensi dan royalti sebagai kompensasi pengorban an waktu, tenaga, keahlian, dan sumber daya langka lainnya.

3. Teknologi dimanfaatkan dengan tujuan dan cara-cara yang sebaik-baiknya.

4. Hak milik intelektual yang terkandung dalam teknologi tersebut mendapatkan perlindungan.

5. Pengalih teknologi mengharapkan bahwa pengalihan teknologinya tudak akan berakibat kehilangan pekerjaan. Untuk itu diperlukan pembagian kerja antara pengalih dan penerima teknologi.

6. Adanya pembagian pasar.

7. Adanya keyakinan pihak pengalih dan penerima teknologi akan terjalin hubungan kerja sama jangka panjang yang saling menguntungkan.

\section{Kesimpulan}

Penyebab beralihnya Teknologi Dari Pemilik teknologi Kepada Negara penerima, hal ini disebabkan karena dengan adanya alih teknologi maka akan terbuka peluang untuk perluasan pasar, peningkatan volume penjualan, peningkatan dana penelitian dan pengembangan, serta untuk memajukan teknologi. Selain itu juga untuk balas jasa yang diberikan berupa royalty, teknologi itu juga akan mendapatkan perlindungan, adanya pembagian pasar,dan juga akan terjalin hubungan kerjasama. Namun dalam alih teknologi ini Indonesia tetap berdasarkan pada perjanjian lisesnsi yang diatur dalam Undang-Undang No.13 Tahun 2016 Tentang Paten dan juga berdasarkan Pasal 1320 KUH Perdata. Sebab sampai saat ini Indonesia belum mempunyai peraturan khusus tentang alih teknologi.

\section{Saran}

Beralihnya teknologi dari pemilik kepada penerima, agar tidak merugikan salah satu pihak, maka sebaiknya sebelum terjadi perjanjian lisensi alih teknologi, bunyi dari klausula-klausula tersebut harus dibuat berdasarkan persetujuan kedua belah pihak. Jangan sampai bunyi klausula itu akan merugikan salah satu pihak khususnya pihak penerima teknologi. Apalagi saat ini Indonesia belum mempunyai peraturan atau undang-undang tentang alih teknologi, maka, seyogyanya hal itu segera harus dipikirakan.

\section{DAFTAR PUSTAKA}

Dewi Astuty, 2001, Perjanjian Lisensi Alih Teknologi Dalam Pengembangan Teknologi Indonesia, PT.Alumni, Bandung.

Insan Budi Maulana,1996 Lisensi Paten, PT. Citra Aditya Bakti, Bandung.

Ita Gambiro, 1978, Pemindahan Teknologi dan Pengaturannya Dalam Peraturan Perundangan, Makalah, dalam : Seminar Aspekaspek Hukum Dari Pengalihan teknologi, Tanggal 2-4 November Binacipta, Manado.

Peter Mahmud Marzuki, 1993, Pengaturan Hukum Terhadap Perusahaanperusahaan Transnasional di Indonesia, Disertasi, Universitas Airlangga, Surabaya. 
Rudhi Prasetya, 1993, Perseroan Terbatas Sebagai Wahana Membahagia kan dan Menestapakan, Makalah, 1 Mei 1993, Surabaya

]Sudikno Mertokusumo, 1998, Mengenal Hukum (Suatu pengantar), Liberty, Yogyakarta.
Sumantoro, 1993, Masalah Pengaturan Alih Teknologi, Alumni, Bandung. Undang-Undang Paten No. 14 Tahun 2001 Undang-Undang No. 13 Tahun 2016 Tentang Paten. 